\title{
Extracurricular Reading for Children from Primary School Course in Bulgaria: Results of a Survey
}

\author{
Rositsa Krasteva ${ }^{(0)}$, Sonya Spasova \\ University of Library Studies and Information Technologies, Sofia, Bulgaria \\ Email: r.krasteva@abv.bg
}

How to cite this paper: Krasteva, R. and Spasova, S. (2021) Extracurricular Reading for Children from Primary School Course in Bulgaria: Results of a Survey. Open Journal of Applied Sciences, 11, 500-522. https://doi.org/10.4236/ojapps.2021.114036

Received: March 18, 2021

Accepted: April 25, 2021

Published: April 28, 2021

Copyright $\odot 2021$ by author(s) and Scientific Research Publishing Inc. This work is licensed under the Creative Commons Attribution International License (CC BY 4.0).

http://creativecommons.org/licenses/by/4.0/

\section{(c) (i) Open Access}

\begin{abstract}
The aim of the research is to obtain information about the current state of children's extracurricular reading in Bulgaria-basis for further development of information skills and competencies. The study refers to the reading practices and interests of primary school students (7 - 11 years). It was implemented in the period March-June 2020 through electronic questionnaires filled out by the parents of 1169 students. The obtained data were processed with the software product SPSS, v19. A comparative analysis between the reading habits and preferences of children of different ages has been prepared. The followings are established: the thematic scope, the types of preferred readings, the motives for independent choice of reading, as well the preferred format, as the influence of the adults in the formation of the young reader. Particular attention is paid to reading in electronic format (e-books or other readings on the Internet).
\end{abstract}

\section{Keywords}

Reading, Reading Matter, Readers, Elementary School Students, Reading Motives

\section{Introduction}

Reading is the foundation of modern human civilization. Every nation that wants to survive, develop and prosper is interested in the education and intellectual growth of its citizens. The intellectual needs of every human person, both in the past and today, are directly related to reading.

It is well known that reading habits are formed in childhood, in parallel with the literacy process. The main attention for their formation is paid in the family, the school and the libraries that the children visit. 
This article is a "snapshot" of readers' preferences and interests, as well as the motives and factors that determine them among students in the age group 7 - 11 years of age, studying in Bulgarian schools. They have a lot in common with the preferences of their peers in Europe and beyond, but there are also elements that differ.

The issue of studying the reading interests and behavior of primary school students today is relatively poorly represented in the Bulgarian scientific literature.

The doctoral dissertations defended in Bulgaria, the object of the research of which is reading in childhood and early adolescence, most often refer to:

- various methodological aspects of the perception of a text when reading in the Bulgarian language teaching [1] [2];

- psychological aspects of reading [3] [4];

- prevention of problems with reproduction and comprehension of read text in students and children with special needs [5] [6] [7];

- development of reading literacy of students in primary school [8];

- the role of libraries in the education of children and students [9].

Data on the reading interests and behavior of primary school students are contained in the dissertations of Iliana Mircheva (1984) [10] and Anna Georgieva (2004) [11], in some publications of Zhecho Atanasov (1973) [12], Lubomira Parizhkova (2019) [13], Eftimova, Sabina (2019) [14] etc.

The general conclusion that can be drawn is that there is a lack of a unified approach and focus in the formation of the reading interests of adolescents.

A number of foreign studies present in detail the state of children's reading today and in the past few years. Among them are: the research of the National Literacy Trust-Great Britain (Clark, 2019) [15], (Kolosova, 2011) [16], (Sushko and Petrova, 2009) [17], (McGeown et al., 2016) [18], (McGeown et al., 2020) [19] etc. Based on the indicated works, a comparative analysis was prepared in the present study.

\section{Purpose, Tasks and Methodology of the Empirical Study}

The purpose of the study is to accumulate data and information from parents of children in primary school for identification, analysis and summarization of children's attitudes, their motives, as well as the factors conducive to reading outside school.

To achieve the set goal, the following tasks are identified:

- Study of the thematic scope and types of reading matters preferred by students from different grades of primary school course

- Clarification of their motives for choosing a book independently

- Study of the influence of adults: parents, teachers, librarians in the formation of the young reader

In the course of the study the following methods were applied: research, analysis and synthesis of the received information, comparative analysis between the 
separate groups of respondents, who participated in the survey: gender and age of the children, location of settlement, educational status of the parents.

To specify the psychometric characteristics of the methods, the following methods for statistical data processing have been applied: descriptive statistics; correlation analysis; factor analysis; single-factor analysis of variance.

\section{Range and Limitations of the Study}

The general population of the study consists of 1169 people, parents or grandmothers of children in the age group 7 - 11 years.

The survey was conducted electronically in the period March-June 2020. The widely used Motivations for Reading Questionnaire (MRQ) or its modification has not been used as a research tool. The questionnaire is specially designed for the purpose of the study-dedicated to providing a broader view of the state of children's extracurricular reading in Bulgaria. It includes both closed-ended questions (with application of the Likert 5-point scale) and semi-open and open questions, requiring free-text answers.

Since the results of the Progress in International Reading Literacy Study (PIRLS) of the 4th grade students are widely known and have been commented on many times, they are not the subject of this publication.

The questionnaire is structured in two sections. The first of them includes 21 questions aimed at revealing the current state of children's reading in Bulgaria.

The second section refers to the demographic characteristics of the survey and is presented in Table 1.

Since according to Regulation (EU) 2016/679 of the European Parliament and of the Council, children cannot be interviewed without the permission of their parents, only the parents themselves have been interviewed. The electronic questionnaire has been sent to all principals of schools with a valid e-mail address in Bulgaria, as well as to the principals of over 100 Bulgarian Sunday schools abroad. They made sure the questionnaire reached the children's parents. The electronic questionnaire was posted on the official websites of Bulgarian schools, on the Facebook page of the Bulgarian community in Montreal, on the official website of the Rodna Stryaha bookstore, etc.

The data received from the respondents were processed using the software product SPSS, v19.

\section{Received Data of the Survey}

\subsection{Thematic Genre Preferences}

The first of the questions in the questionnaire aims to establish the thematic preferences of students. The received data are presented in the following figures.

The most preferred thematic genre is "nature and animals" $-64.6 \%$, and in larger cities this genre is more popular, /cities with a population of 1 million to 500,000 inhabitants (Figure 1).

Among the preferred genres for Bulgaria also come comics-22.4\% where the 
Table 1. Demographic characteristics of the survey.

\begin{tabular}{|c|c|c|c|}
\hline Number $\mathbf{N}$ & Percent \% & & \\
\hline \multirow{3}{*}{ Respondent } & mother & 1078 & 92.3 \\
\hline & father & 77 & 6.6 \\
\hline & grandmother & 12 & 1.1 \\
\hline \multirow{7}{*}{$\begin{array}{l}\text { Educational level } \\
\text { of the respondent }\end{array}$} & primary education & 20 & 1.7 \\
\hline & secondary education & 105 & 9 \\
\hline & secondary vocational education & 181 & 15.4 \\
\hline & bachelor & 282 & 24.1 \\
\hline & master & 504 & 43.1 \\
\hline & doctor and higher scientific degree/title & 56 & 4.8 \\
\hline & student & 21 & 1.8 \\
\hline \multirow{8}{*}{ Populated location size } & with over 1 million inhabitants & 289 & 24.7 \\
\hline & with up to 500,000 inhabitants & 224 & 19.2 \\
\hline & with up to 100,000 inhabitants & 184 & 15.8 \\
\hline & with up to 50,000 inhabitants & 178 & 15.2 \\
\hline & with up to 10,000 inhabitants & 165 & 14.1 \\
\hline & with up to 5000 inhabitants & 59 & 5.1 \\
\hline & with up to 1000 inhabitants & 26 & 2.2 \\
\hline & with up to 500 inhabitants & 43 & 3.7 \\
\hline Bulgarians living abroad & $\begin{array}{l}\text { Families living in Austria, Belarus, } \\
\text { Great Britain, Germany, Ireland, Italy, } \\
\text { Spain, Canada, Cyprus, The Netherlands, } \\
\text { Norway, UAE, USA, Czech Republic, Sweden }\end{array}$ & 138 & 11.8 \\
\hline \multirow{2}{*}{ Gender of the child } & girls & 613 & 52.44 \\
\hline & boys & 556 & 47.56 \\
\hline \multirow{5}{*}{ Age of the child } & 7 years of age & 144 & 12.3 \\
\hline & 8 years of age & 176 & 15.06 \\
\hline & 9 years of age & 229 & 19.6 \\
\hline & 10 years of age & 254 & 21.7 \\
\hline & 11 years of age & 366 & 31,3 \\
\hline \multirow[b]{2}{*}{ Type of school } & initial, primary, secondary & 1070 & 91.6 \\
\hline & $\begin{array}{l}\text { with intensive study of a foreign language, } \\
\text { mathematics, arts }\end{array}$ & 98 & 8.4 \\
\hline
\end{tabular}

number of their fans is also the highest in large cities with over 1 million inhabitants; there it is $33.1 \%$.

It is noticeable the fact that the preferences for the theme "nature and animals" are a little more than those for fairy tales. Fairy tales, according to previous researchers, are the most preferred reading in this age group (Atanasov, 


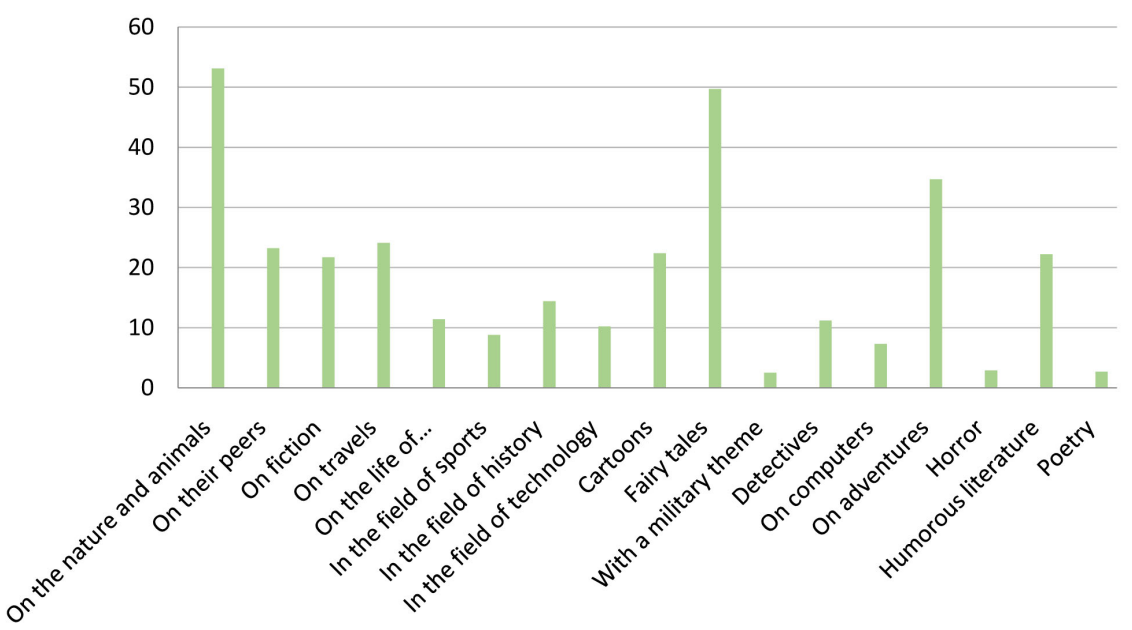

Figure 1. Thematic genre preferences.

1973) [12], (Kolosova, 2011) [16], (Sushko, and Petrova, 2009) [17]. An interesting phenomenon is that in the information society and with early access to electronic devices of modern children, it is too early to read popular fairy tales or they know their content from cartoons. Already before entering the first grade, some of the children can read completely independently and do so as their parents offer them books with encyclopaedic content, due to the presence in them of short but meaningfully completed informative texts. Of course, the cognitive activity of children should be encouraged, but with a precise determination of the amount of factual information contained in encyclopaedias. With the pursuit of a wider information awareness it seems to neglect the building of emotional intelligence, defining and recognizing one's own emotions, which is the basis for building a sense of sympathy, empathy or at least tolerance for other people's opinions and feelings.

Another interesting fact is the shift of the reading interests of contemporary Bulgarian children in the direction of comics-a genre that has so far been poorly present in their favourite readings. Some authors (McGeown et al., 2020) [19] consider the reading of comics as a reading for fun or one that children practice when they are tired or bored. And their supply on the book market both at home and abroad has increased.

In terms of age preferences, the results are as follows:

For the seven-year-olds (Figure 2), as expected, the most preferred are the fairy tales $19.2 \%$, followed by the readings with sports themes $16.0 \%$ and Nature and animals-15.8\%. The poetry is fourth in this age group (14.0\%). With increasing age, interest in them increases in percentage (respectively $24 \%$ for eightyear-olds, $22 \%$ for nine-year-olds and about $20 \%$ for ten-eleven-year-olds), but given the richer palette of readings of the older children, it is not among the most preferred genres for them.

Eight-year-olds (Figure 3) still have a relatively high level of interest in fairy tales-19.2\%, there is an increased interest in readings, describing travels- 


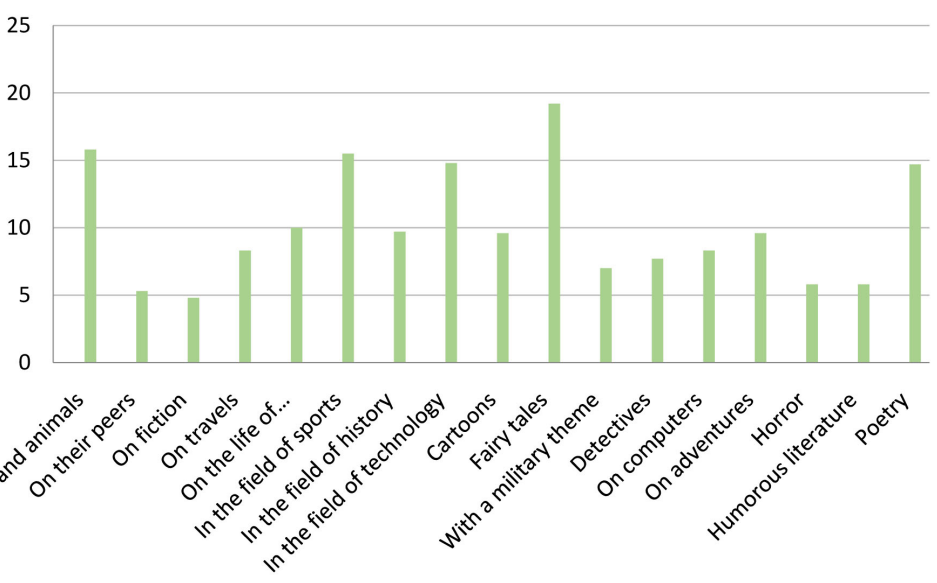

Figure 2. Genre-thematic preferences of seven-year-old children.

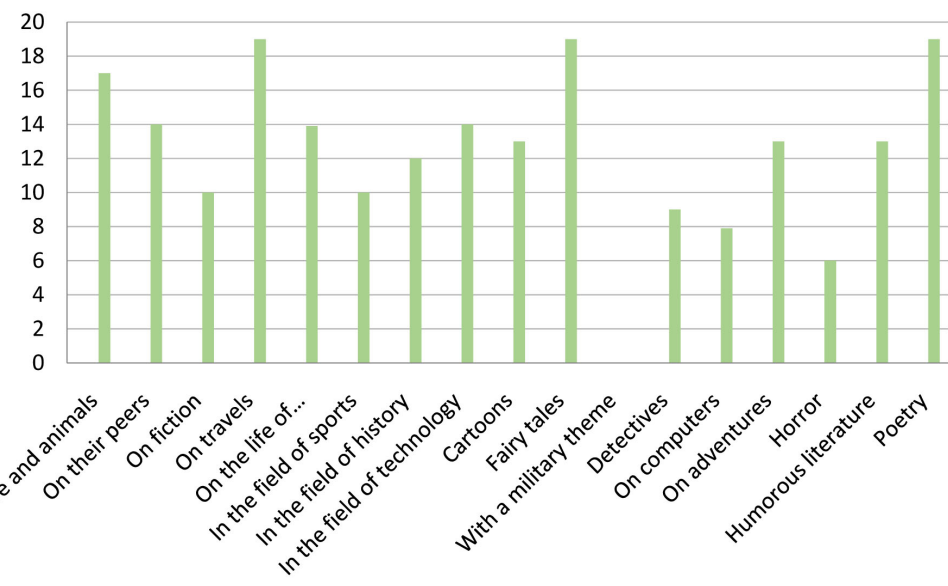

Figure 3. Genre-thematic preferences of eight-year-old children.

$19.1 \%$ (for comparison, the percentage of seven-year-olds is 8.8), their peers$13.5 \%$ (6.3\% for seven-year-olds), comics 13.1 (8.8\% for seven-year-olds) and, as already noted, the poetry.

Among the preferences typical for this age group (nine-year-old childrenpresented on Figure 4)-remarkable personalities, adventures (Therrell, 2002) [20] we see that there are also books with military themes and horrors. This is a worrying fact.

The palette of genre-thematic preferences of ten-year-olds is significantly wider (Figure 5). It is interesting the fact, that among the favorites here are: readings in the field of sports, comics, humor, i.e. there is a slight predominance of entertaining readings. Since no more specific information on the causes is available, the results are reported only. The data from a survey conducted by Elena Davcheva in 2014, p. 178 are similar [21]. "Thematically, it is also observed a decline to lower literary niches-the researcher notes.

Eleven-year-olds (Figure 6) are expected to lose interest in fairy tales, nature and animals. Readings in the field of fiction, detective and adventure literature, readings related to computers and others have come to the fore. It is worrying 


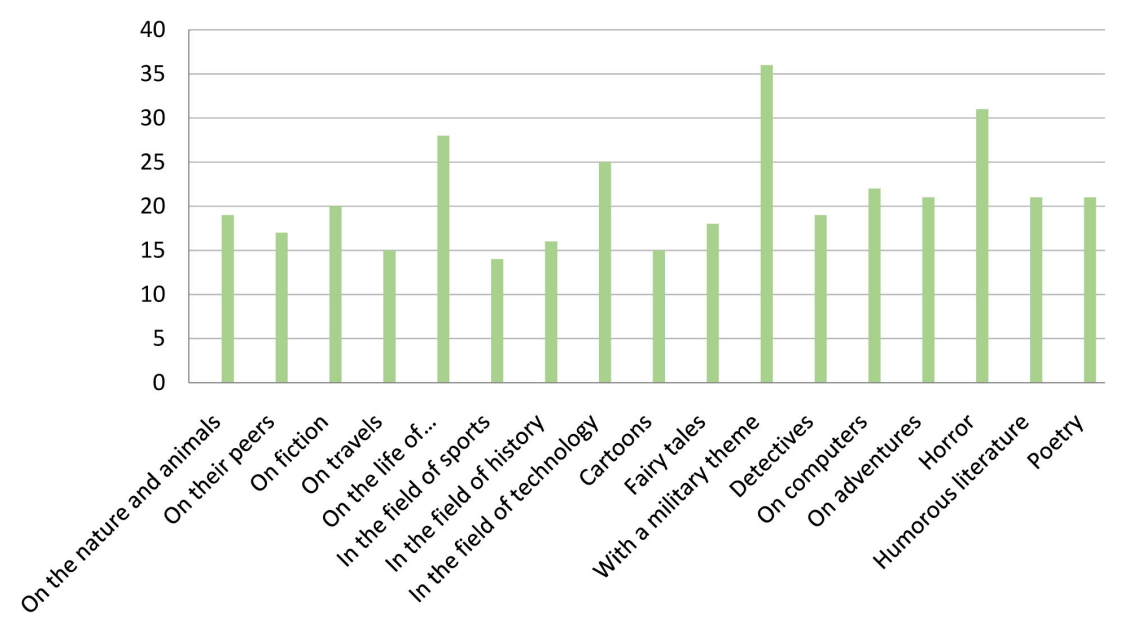

Figure 4. Genre-thematic preferences of nine-year-old children.

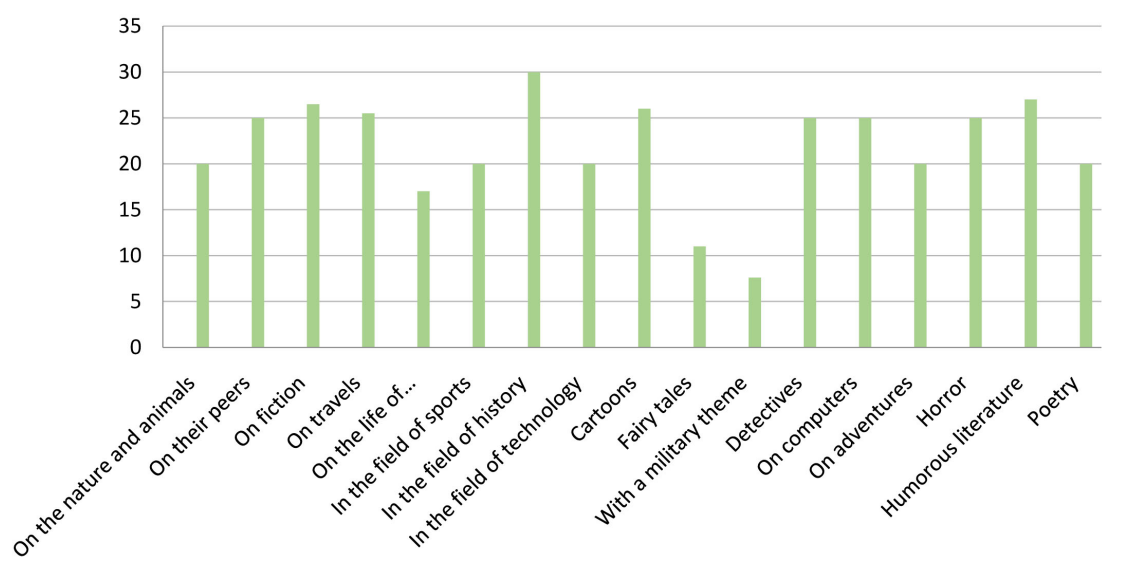

Figure 5. Genre-thematic preferences of ten-year-old children.

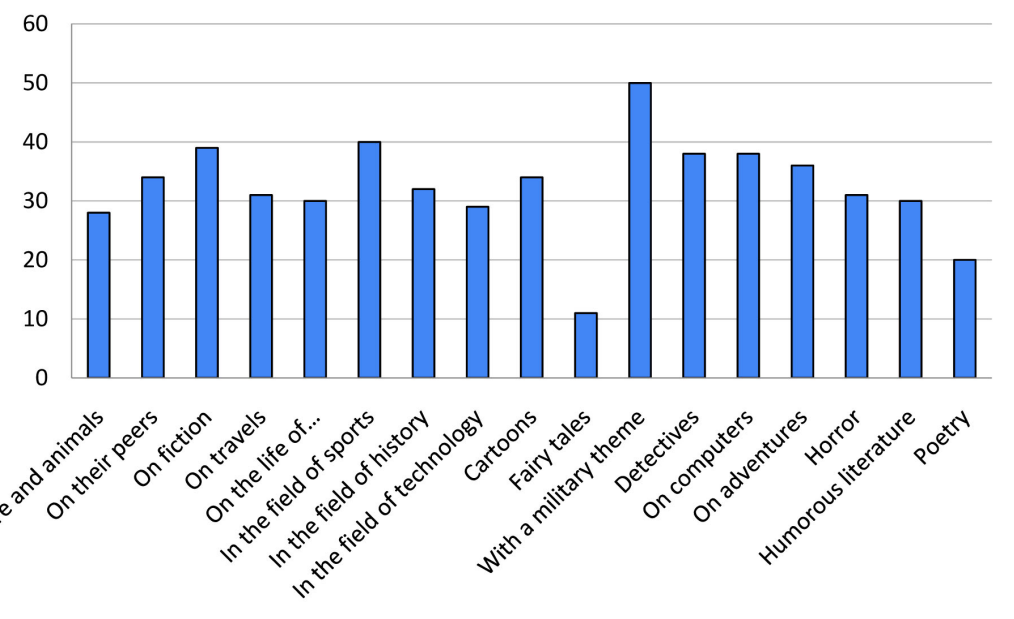

Figure 6. Genre-thematic preferences of eleven-year-old children.

that military-themed readings predominate. Probably influenced by television, computer games, the mentality of their environment, the onset of puberty, etc., the children become accustomed to the subject of wars and related violence, and 
unconsciously it begins to become a naturally present and uncritically perceived part of their daily lives.

Another factor on the basis of which statistically significant differences in preferences are formed is gender. The influence of the child's gender on the genre thematic preferences is presented in Figure 7.

The presented data show that the differentiation in the preferences of boys and girls in the period between 7 and 11 years of age is very clear. This fact is noted by many researchers (Kolosova, E., 2011: 27; Laura Scholes, 2019) [16] [22].

\subsection{The Most Commonly Used Types of Publications}

In response to the next question from the questionnaire "Which type of reading does your child most often turn to?", the results are as follows (Figure 8):

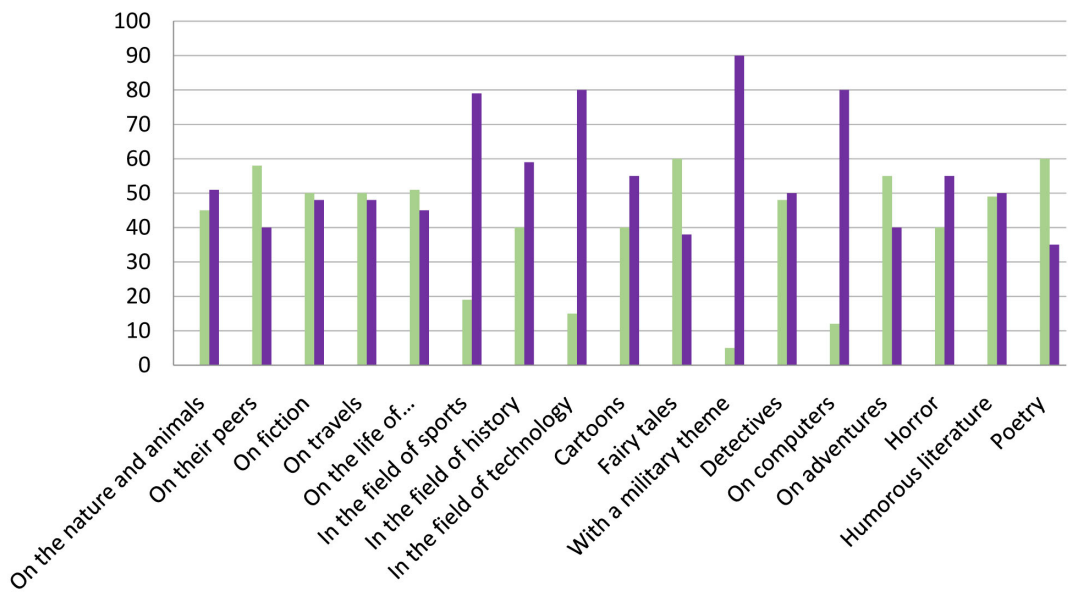

Figure 7. Genre-thematic preferences (factor-gender). Violet colour-boys; Green colour-girls.

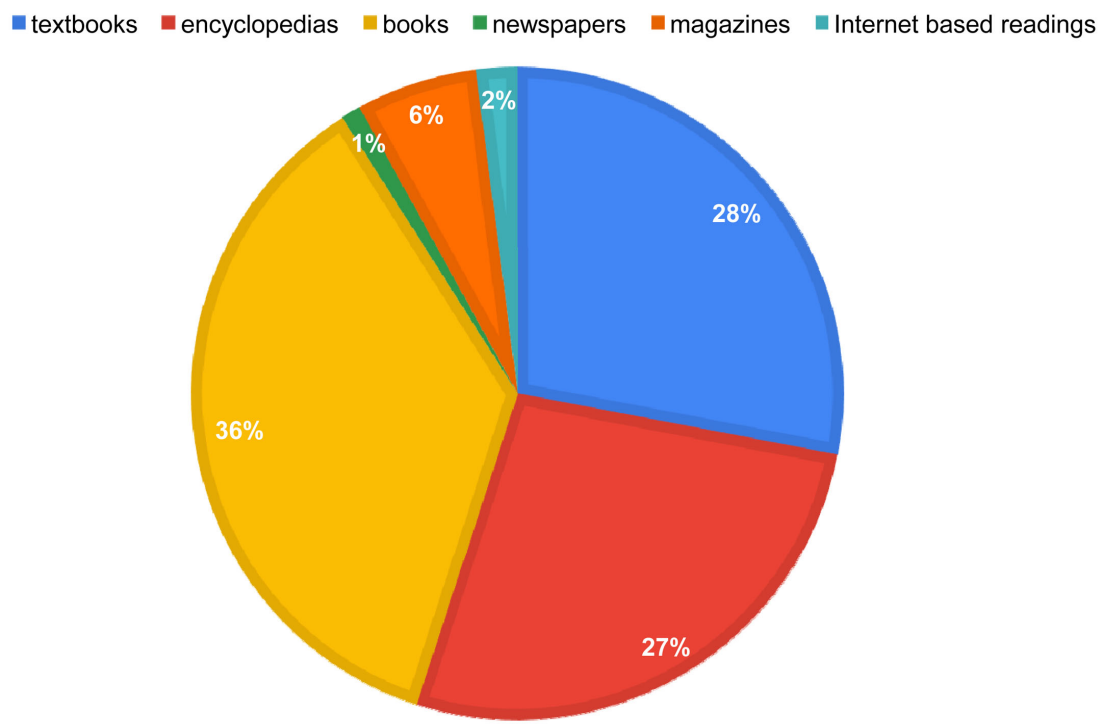

Figure 8. The most commonly used types of publications. 
From the presented in Figure 8 data it becomes clear, that the most common readings are books, followed by textbooks and encyclopaedias. It is noticeable the fact that Bulgarian children are less inclined to read newspapers and magazines. A comparative analysis between boys and girls (see Table 3 ) shows, that girls are more likely to read these publications.

A large-scale survey conducted in Russia in 2011 presents the types of publications preferred by Russian children in the same age group (Kolosova, E., 2011: 45) [16]. "In addition to the educational textbooks, younger students most often read books (62\%), followed by magazines (49\%) and encyclopaedias (30\%). Less than $5 \%$ of children regularly use other types of texts in various media (newspapers, comics, advertisements, audio-books, texts on the Internet)."

Research by Sarah P. McGeown and her team [18] gives an idea of age and gender-the two most important characteristics that influence a child's preferred edition. The results of the current questionnaire survey in this direction are presented in Table 2 and Table 3. The results exceed 100\%, as the respondents gave more than one answer. We observe a relatively stable trend that with the increase of the age of the child-the percentage of those who prefer/dislike a certain type of publication also increase.

In response to Question 4 (Figure 9) "Are adult readings of interest to the child" it is evident that there is a tendency to shift at an earlier age the interest in readings for older people (mainly books, magazines, encyclopaedias), and when they objectively reach puberty, children distance themselves from reading books as an activity and a means of learning about the world, themselves and others.

Do Bulgarian children read regularly and at own will? From the data presented in Figure 10 we can see that slightly more than a half (53\%) of the children read regularly, $33.4 \%$ have read some part of certain reading outside the school materials in the last month, and $12.7 \%$ have not read. The results are similar to those from the conducted in the 2017/2018 annual survey of the National Literacy Trust, Great Britain, among students from the Great Britain [15].

Table 2. Preferred type of publication (age factor).

\begin{tabular}{|c|c|c|c|c|c|c|c|}
\hline \multicolumn{2}{|c|}{ reading matter } & \multirow{2}{*}{$\begin{array}{c}\text { textbooks } \\
61.1 \%\end{array}$} & \multirow{2}{*}{$\begin{array}{l}\text { books } \\
73.6 \%\end{array}$} & \multirow{2}{*}{$\begin{array}{c}\text { encyclopaedias } \\
44.4 \%\end{array}$} & \multirow{2}{*}{$\begin{array}{c}\text { magazines } \\
6.9 \%\end{array}$} & \multirow{2}{*}{$\begin{array}{c}\text { newspapers } \\
4.1 \%\end{array}$} & \multirow{2}{*}{$\begin{array}{c}\text { Internet based } \\
\text { readings }\end{array}$} \\
\hline & 7 years & & & & & & \\
\hline & 8 years & $61.3 \%$ & $77.2 \%$ & $48.8 \%$ & $11.5 \%$ & $1.1 \%$ & $3.4 \%$ \\
\hline \multirow[t]{3}{*}{ age } & 9 years & $57.6 \%$ & $75.9 \%$ & $51.9 \%$ & $10.4 \%$ & $0 \%$ & $2.6 \%$ \\
\hline & 10 years & $58.5 \%$ & $76.3 \%$ & $48.8 \%$ & $11.0 \%$ & $1.5 \%$ & $4.3 \%$ \\
\hline & 11 years & $54.4 \%$ & $72.6 \%$ & $45.3 \%$ & $14.7 \%$ & $1.09 \%$ & $7.6 \%$ \\
\hline
\end{tabular}

Table 3. Preferred type of publication (gender factor).

\begin{tabular}{cccccccc}
\hline \multicolumn{2}{r}{ reading matter } & textbooks & books & encyclopaedias & magazines & newspapers & $\begin{array}{c}\text { Internet based } \\
\text { readings }\end{array}$ \\
\hline \multirow{2}{*}{ gender } & girl & $49.9 \%$ & $56.4 \%$ & $46.3 \%$ & $62.3 \%$ & $62.5 \%$ & $48.1 \%$ \\
& boy & $50.1 \%$ & $43.6 \%$ & $53.7 \%$ & $37.7 \%$ & $37.5 \%$ & $51.9 \%$ \\
\hline
\end{tabular}




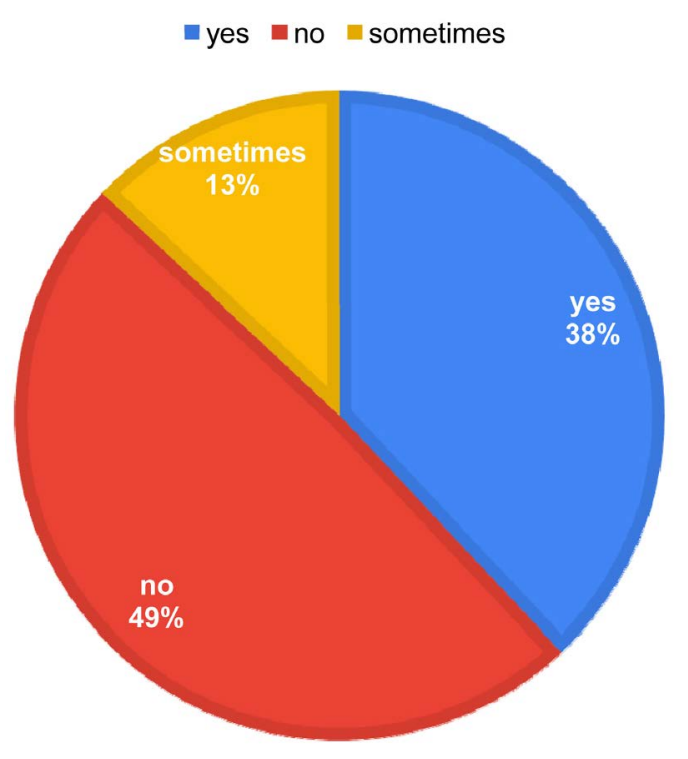

Figure 9. Interest in reading for adults.

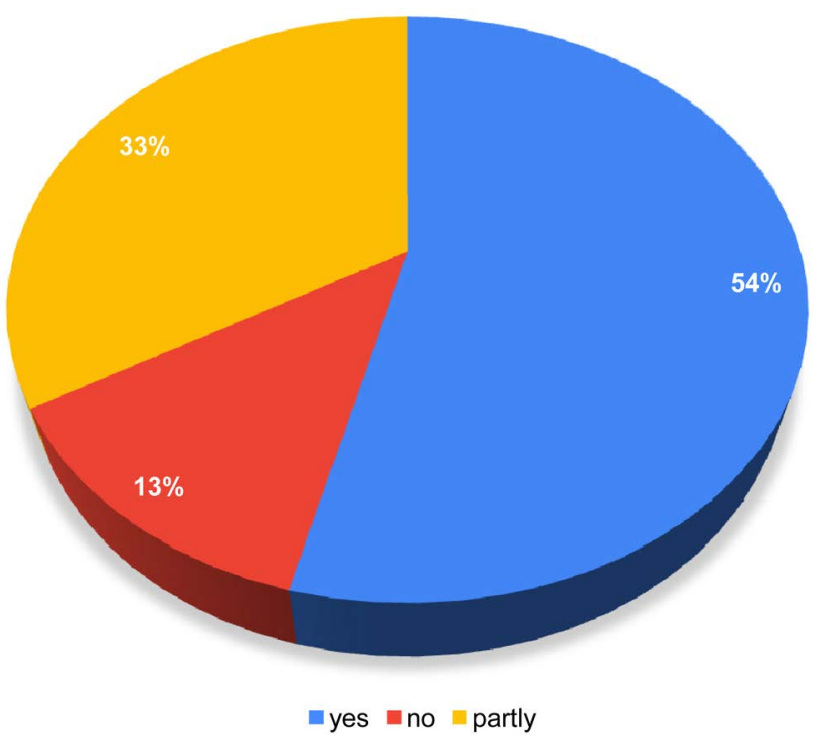

Figure 10. Reading outside the study materials during the last month.

The age distribution of the children is presented in Table 4.

From the data presented in Table 4 it is evident that with the increasing the age of students, their desire to read outside the compulsory school materials gradually decreases.

No statistically significant gender difference was reported.

The main social institutions influencing the formation of the reader in adolescence include, above all, the family, the school and the libraries. Their interaction gives visible results and has proven its usefulness.

The role of the family in shaping the child's attitude towards books and reading is extremely important. "Is the book a desirable gift for children today?this is the next question on the questionnaire. The results are presented in Table 5. 
Table 4. Reading outside the study materials during the last month (age factor).

\begin{tabular}{cccccccc}
\hline $\begin{array}{c}\text { Reading outside the study } \\
\text { materials in the last month }\end{array}$ & $\mathrm{N}$ & $\mathrm{SD}$ & $\mathrm{M}$ & Sig. & $\mathrm{F}$ & Min. & Max. \\
\hline seven-year-olds & 144 & 0.2 & 2.35 & & & & \\
eight-year-olds & 176 & 0.4 & 2.31 & & & & \\
nine-year-olds & 229 & 0.3 & 2.23 & 0.000 & 5.07 & 1 & 3 \\
ten-year-olds & 254 & 0.5 & 2.14 & & & & \\
eleven-year-olds & 366 & 0.2 & 2.12 & & & & \\
\hline
\end{tabular}

Table 5. Books as presents by a child to their friends (factor-educational status of the parents).

\begin{tabular}{|c|c|c|c|c|c|}
\hline Educational status of the parent ${ }^{*}$ & $\mathrm{~N}$ & SD & M & $\mathrm{F}$ & Sig. \\
\hline primary & 20 & 0.50 & 1.40 & & \\
\hline secondary & 104 & 0.67 & 1.75 & & \\
\hline secondary vocational & 186 & 0.63 & 2.01 & & \\
\hline higher (bachelor) & 286 & 0.49 & 1.97 & 6.83 & 0.000 \\
\hline higher (master) & 495 & 0.53 & 1.92 & & \\
\hline higher (doctor) & 56 & 0.56 & 2.11 & & \\
\hline student & 22 & 0.39 & 1.82 & & \\
\hline
\end{tabular}

Most often the parent in this case is the mother, as $92.3 \%$ of the respondents who filled in the questionnaire are mothers.

In processing the obtained data, the method of single-factor analysis of variance was used.

The results show that the educational status of the parents or the grandmother and grandfather, who take care of the child is essential for its place as a desired gift and one that the children would give to their friends (Table 6).

\subsection{The Book as a Gift Desired by the Child}

A statistically significant difference, although small, was observed in boys and girls (Table 7, Table 8). As expected, the book is more popular as a gift for the girls.

Age is also a factor influencing preferences. As children get older, the book becomes less and less desirable (Table 9, Table 10).

The composition of the home library, reflecting the taste, professional and non-professional interests, sometimes of several generations, sometimes largely determines not only the attitude to the book, but also the range of preferred readings and influences the formation of a fully socialized personality. There is a real need for parents to focus on valuable readings from the world classics of children's literature, forming a value system and proper social orientation. The data from the survey in this direction (Question 7 "Who advises the child what to read") are presented in Figure 11. We see that more than half of parents advise their children when choosing what to read, $24.2 \%$ of them hand-over this task of teachers; only $2.7 \%$ - to librarians, and the rest rely on friends or on the child's own initiative. 


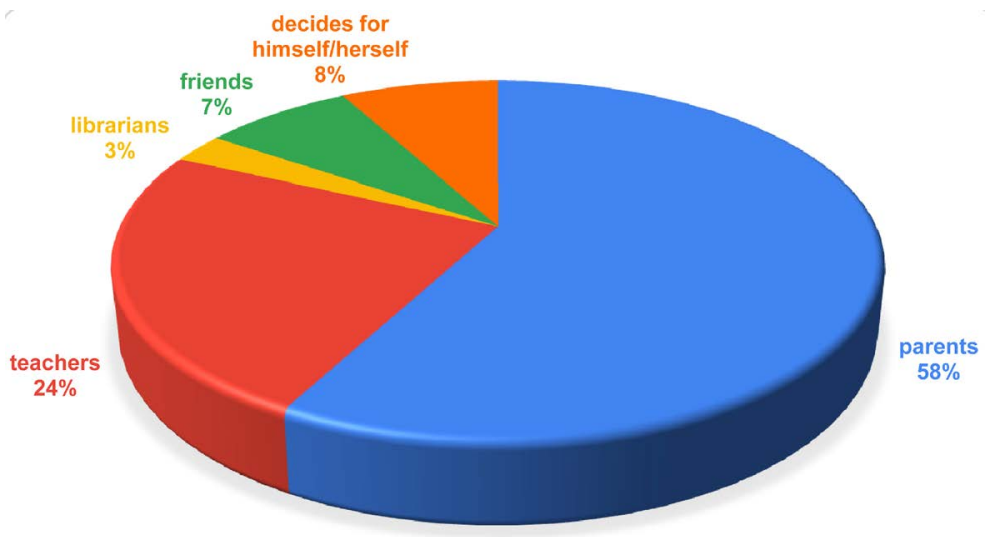

Figure 11. Who most often advises the child what to read.

Table 6. The book as a gift desired by the child (factor-educational status of the parents).

\begin{tabular}{cccccc}
\hline Educational status of the parent & $\mathrm{N}$ & $\mathrm{SD}$ & $\mathrm{M}$ & $\mathrm{F}$ & Sig. \\
\hline primary & 20 & 0.50 & 1.60 & & \\
secondary & 104 & 0.41 & 1.79 & & \\
secondary vocational & 186 & 0.43 & 1.74 & & \\
higher (bachelor) & 286 & 0.30 & 1.90 & 5.91 & 0.000 \\
higher (master) & 495 & 0.46 & 2.08 & & \\
student & 22 & 0.51 & 1.89 & & \\
higher (doctor) & 56 & 0.45 & 2.16 & & \\
\hline
\end{tabular}

Table 7. Books as presents by a child to their friends (factor-gender of the child).

\begin{tabular}{cccccc}
\hline Gender of the child & N & SD & M & F & Sig. \\
\hline girl & 613 & 0.50 & 1.95 & & \\
boy & 556 & 0.61 & 1.90 & 1.85 & 0.017 \\
\hline
\end{tabular}

Table 8 . The book as a gift desired by the child (factor-gender of the child).

\begin{tabular}{cccccc}
\hline Gender of the child & $\mathrm{N}$ & $\mathrm{SD}$ & $\mathrm{M}$ & $\mathrm{F}$ & Sig. \\
\hline girl & 613 & 0.30 & 1.90 & & \\
boy & 556 & 0.43 & 1.75 & & \\
\hline
\end{tabular}

Table 9. Books as presents by a child to their friends (factor-age of the child).

\begin{tabular}{cccccc}
\hline Age of the children & $\mathrm{N}$ & $\mathrm{SD}$ & $\mathrm{M}$ & $\mathrm{F}$ & Sig. \\
\hline seven-year-olds & 144 & 0.51 & 2.07 & & \\
eight-year-olds & 176 & 0.62 & 2.10 & & 0.000 \\
nine-year-olds & 229 & 0.55 & 1.97 & 41.84 & \\
ten-year-olds & 254 & 0.55 & 1.88 & & \\
eleven-year-olds & 366 & 0.52 & 1.79 & \\
\hline
\end{tabular}


Table 10. The book as a gift desired by the child (factor-age of the child).

\begin{tabular}{cccccc}
\hline Age of the children & $\mathrm{N}$ & $\mathrm{SD}$ & $\mathrm{M}$ & $\mathrm{F}$ & Sig. \\
\hline seven-year-olds & 144 & 0.34 & 1.89 & & \\
eight-year-olds & 176 & 0.36 & 1.84 & & \\
nine-year-olds & 229 & 0.36 & 1.84 & 2.45 & 0.011 \\
ten-year-olds & 254 & 0.37 & 1.83 & & \\
eleven-year-olds & 366 & 0.39 & 1.80 & & \\
\hline
\end{tabular}

As we can see, the presence of librarians as mediators and mentors in the process of directing children to valuable readings is not very great.

One of the most authoritative studies of reading motivation characterizes it as a factor that reflects "The drive to read resulting from a comprehensive set of an individual's beliefs about, attitudes toward, and goals for reading." [23].

Undoubtedly, the motivation to read in children is due to many different factors, both internal and external [24] [25] [26] [27].

\subsection{Motives for Independent Choice of Reading Matter}

Question 10. from the questionnaire refers to the motives of the children for independent choice of reading matter. The most common motive is a read book from a series/cycle $(45.9 \%)$, followed by the attractiveness of the title (31.5\%), the cover (28.6\%) and others. The factors that most influence the motives for choosing to read are the age and gender of the child. Data on the influence of these two factors are presented in Table 11 and Table 12.

The best results in terms of comprehension of the read text are observed when the internal motivation is combined with the external one [28].

The results presented in Table 11 and Table 12 show that there is observed both external motivation (recommendation from a friend, teacher or other close person) and internal (all other answers). As they grow, children become more socialized-there is a gradual increase in external motivation observed.

\subsection{Use of the Internet and Preference for Reading Books in Electronic Format}

To what extent are modern children in the age group 7 - 11 years connected with the Internet?

From the data presented in Figure 12, it becomes clear that 91.5\% regularly use the Internet at home, $2.9 \%$-at school, $2.5 \%$-in the parent's office, everywhere-by phone, both at home and at school, "My son studies entirely on a school laptop. After the morning classes he uses it to prepare homework. There is no time, and there is no opportunity for recreational surfing"-mother of a third grade student from an international Scandinavian school responded. The children, who do not use the Internet, in this age group, are only $3.1 \%$. As the survey was conducted during a period of a distance learning during the COVID-19 pandemic, the question remains how these children attended school. 


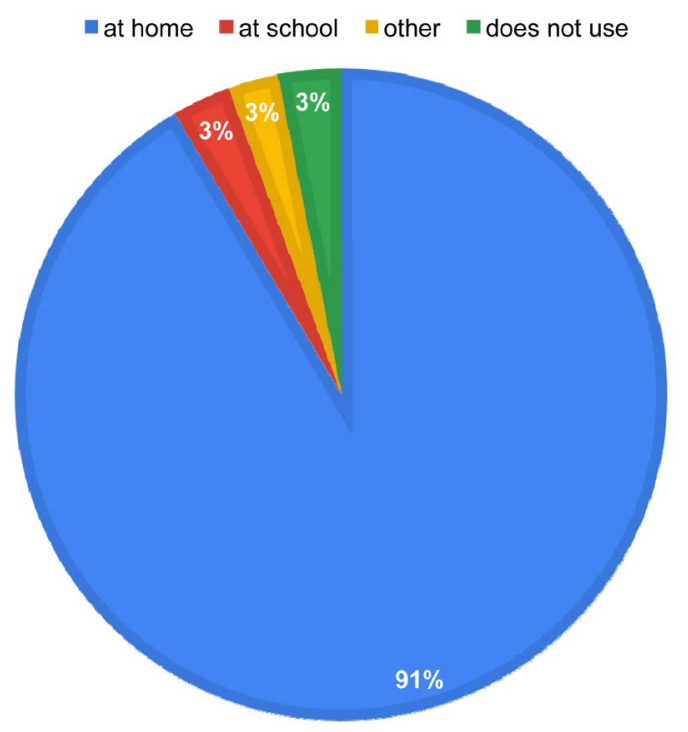

Figure 12. Where children most often use the internet.

Table 11. Motives for independent choice of reading matter (factor-gender).

\begin{tabular}{cccccccc}
\hline $\begin{array}{c}\text { Gender } \\
\text { of the } \\
\text { children }\end{array}$ & $\begin{array}{c}\text { Likes } \\
\text { the } \\
\text { title }\end{array}$ & $\begin{array}{c}\text { Likes } \\
\text { the } \\
\text { author }\end{array}$ & $\begin{array}{c}\text { Likes } \\
\text { the } \\
\text { cover }\end{array}$ & $\begin{array}{c}\text { Advertising } \\
\text { of the } \\
\text { publication }\end{array}$ & $\begin{array}{c}\text { Shared on } \\
\text { Internet }\end{array}$ & $\begin{array}{c}\text { Likes this } \\
\text { series/cycle }\end{array}$ & $\begin{array}{c}\text { Recommendation } \\
\text { from a teacher, } \\
\text { friend, relative }\end{array}$ \\
\hline girl & $31.4 \%$ & $57.3 \%$ & $48.5 \%$ & $51.6 \%$ & $47.9 \%$ & $55.5 \%$ & $54.6 \%$ \\
boy & $30.5 \%$ & $42.7 \%$ & $51.5 \%$ & $48.4 \%$ & $52.1 \%$ & $44.5 \%$ & $45.4 \%$ \\
\hline
\end{tabular}

Table 12. Motives for independent choice of reading matter (factor-age).

\begin{tabular}{cccccccc}
\hline $\begin{array}{c}\text { Age of } \\
\text { the children }\end{array}$ & $\begin{array}{c}\text { Likes } \\
\text { the title }\end{array}$ & $\begin{array}{c}\text { Likes the } \\
\text { author }\end{array}$ & $\begin{array}{c}\text { Likes } \\
\text { the } \\
\text { cover }\end{array}$ & $\begin{array}{c}\text { Advertising } \\
\text { of the } \\
\text { publication }\end{array}$ & $\begin{array}{c}\text { Shared } \\
\text { on } \\
\text { Internet }\end{array}$ & $\begin{array}{c}\text { Likes this } \\
\text { series/cycle }\end{array}$ & $\begin{array}{c}\text { Recommendation } \\
\text { from a teacher, } \\
\text { friend, relative }\end{array}$ \\
\hline seven-year-olds & $12.3 \%$ & $9.4 \%$ & $23.4 \%$ & $12.6 \%$ & $7.7 \%$ & $9.8 \%$ & $7.8 \%$ \\
eight-year-olds & $15.1 \%$ & $12.0 \%$ & $20.5 \%$ & $11.3 \%$ & $12.0 \%$ & $11.7 \%$ & $19.6 \%$ \\
nine-year-olds & $19.6 \%$ & $17.1 \%$ & $16.4 \%$ & $23.9 \%$ & $17.1 \%$ & $19.3 \%$ & $15.7 \%$ \\
ten-year-olds & $21.7 \%$ & $18.8 \%$ & $14.6 \%$ & $18.9 \%$ & $16.2 \%$ & $22.3 \%$ & $25.5 \%$ \\
eleven-year-olds & $31.3 \%$ & $42.7 \%$ & $14.1 \%$ & $33.3 \%$ & $47.0 \%$ & $36.7 \%$ & $31.4 \%$ \\
\hline
\end{tabular}

Do children read books online in Internet? Most children don't read (71.5\%), $8.6 \%$ read books on the computer screen and $16.8 \%$ on another electronic device. $3.1 \%$ of parents print the electronic texts they offer their child on paper. The preference for e-books again, as in the previous question, is not so much influenced by gender. It increases with the age of the children (Table 13). The results are similar in the study by Sarah P. McGeown and team-“Age is a stronger predictor of engagement with digital texts." [18]. A statistically significant difference was also found depending on the settlement where the child's family lives. Children living in larger settlements are more likely to read books in electronic format (Table 14). 
Table 13. Preference for reading books in electronic format (factor-age).

\begin{tabular}{cccccccc}
\hline $\begin{array}{c}\text { Preference for reading books in } \\
\text { electronic format }\end{array}$ & $\mathrm{N}$ & $\mathrm{SD}$ & $\mathrm{M}$ & Sig. & $\mathrm{F}$ & Min. & Max. \\
\hline seven-year-olds & 144 & 0.5 & 1.21 & & & & \\
eight-year-olds & 176 & 0.2 & 1.57 & & & & \\
nine-year-olds & 229 & 0.6 & 1.53 & 0.000 & 39.64 & 1 & 4 \\
ten-year-olds & 254 & 0.1 & 1.69 & & & & \\
eleven-year-olds & 366 & 0.3 & 1.93 & & & & \\
\hline
\end{tabular}

Table 14. Preference for reading books in electronic format (factor-settlement location).

\begin{tabular}{ccccccc}
\hline Preference for reading books in electronic format & $\mathrm{N}$ & $\mathrm{SD}$ & $\mathrm{M}$ & Sig. & $\mathrm{F}$ & Min. Max. \\
\hline settlement with over 1 million inhabitants & 315 & 0.7 & 1.84 & 0.000 & & \\
settlement with up to 500,000 inhabitants & 210 & 0.8 & 1.69 & 0.000 & & \\
settlement with up to 100,000 inhabitants & 172 & 0.8 & 1.49 & 0.003 & & \\
settlement with up to 50,000 inhabitants & 166 & 0.8 & 1.47 & 0.000 & 42.88 & 1 \\
settlement with up to 10,000 inhabitants & 144 & 0.7 & 1.42 & 0.000 & & \\
settlement with up to 5000 inhabitants & 56 & 0.1 & 1.43 & 0.008 & & \\
settlement with up to 1000 inhabitants & 24 & 0.2 & 1.28 & 0.011 & \\
settlement with up to 500 inhabitants & 40 & 0.3 & 1.21 & 0.000 & \\
\hline
\end{tabular}

Where your child usually reads outside of school?

Most often children read at home (91.4\%). Grandmothers and grandfathers are also a factor that stimulates children's reading. $6.6 \%$ of children read most often in their home. The number of children reading in a library is relatively low (1\%). The same goes for the number of children who most often read while travelling by some transport-public or parents' car.

\subsection{Where Do Children Most Often Use Books from}

Where do children most often use books from? The percentage distribution of responses is presented in Figure 13.

It is noticeable the fact that too few children can rely on the school library.

Parents who indicated the answer "other" most often explained that they buy books from electronic-book stores, and a few that they borrow from friends.

Do children read during the school holidays?

The answers to this question are distributed as follows: (See Figure 14).

It is noticeable the fact that almost half of the children choose readings that are of interest to them, i.e. they demonstrate internal motivation to a greater extent than external motivation, related to reading books recommended in connection with the learning process. The answers received confirm the fact that the role of the school as a major corrective and factor, in addition to the family, in building the worldview and value orientation of adolescents is largely eliminated. 
" home library $\quad$ school library $\quad$ city/community center library $\quad$ book store $\quad$ other

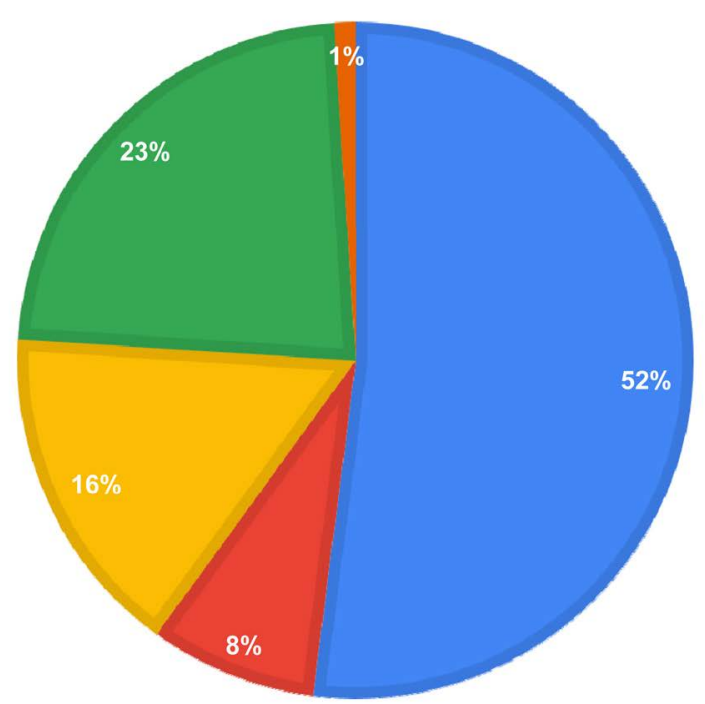

Figure 13. Where do children most often use books from.

\begin{tabular}{cc}
\hline yes, books that are interesting to him/her (blue) & $50 \%$ \\
yes, books from the list of literature he/she receives at school (red) & $41 \%$ \\
yes, mainly readings on the internet (yellow) & $2 \%$ \\
no, prefers other activities (green) & $7 \%$ \\
\hline
\end{tabular}

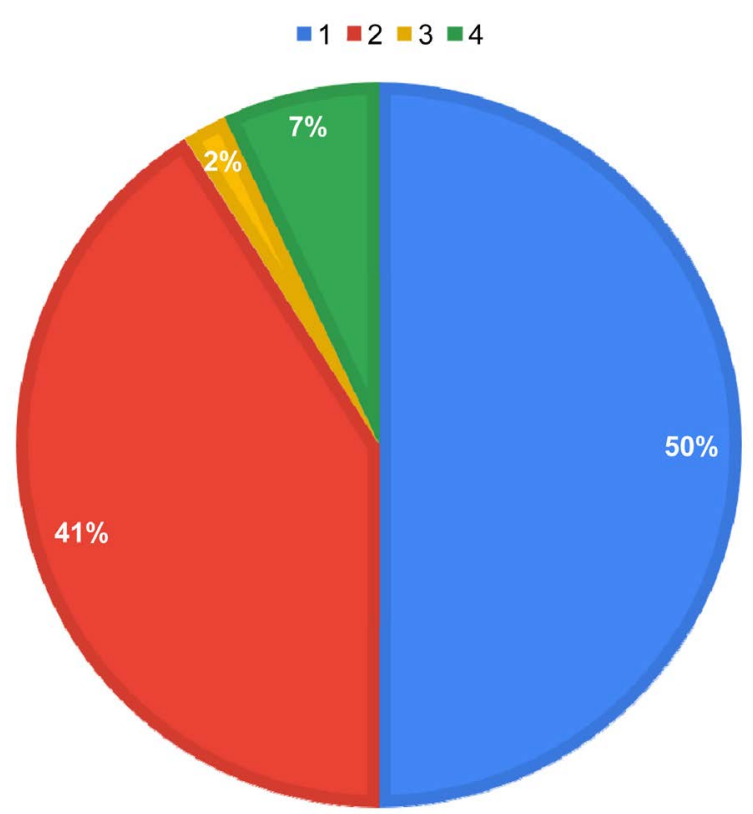

Figure 14. Reading during the school holidays.

The obtained results show the indisputable fact-parents with a higher level of education raise and educate more literate children. A statistically significant difference in the answers of the respondents was reported on the factor of educational status of the parents. The data are presented in Table 15. 
Table 15. Reading during the school holidays (factor-educational status of the parents).

\begin{tabular}{cccccc}
\hline Educational status of the parents & $\mathrm{N}$ & $\mathrm{SD}$ & $\mathrm{M}$ & $\mathrm{F}$ & Sig. \\
\hline primary & 20 & 0.1 & 1.60 & & \\
secondary education & 104 & 0.6 & 2.38 & & \\
secondary vocational education & 186 & 0.6 & 2.23 & & \\
higher education/bachelor & 286 & 0.3 & 2.57 & 14.55 & 0.001 \\
higher education/master & 495 & 0.3 & 2.57 & & \\
doctor and higher degree & 56 & 0 & 2.68 & & \\
student & 22 & 0.1 & 2.55 & & \\
\hline
\end{tabular}

\subsection{Reading in the Family and among the Child's Circle of Friends}

Who were the favourite authors for children and which books were favourite to the parents? Are they willing to recommend them to their children today?

Here are the authors and titles most preferred by parents:

1) Astrid Lindgren

Nearly a quarter of the respondents named her as a favourite author, associating her mostly with her novel "Pippi Longstocking". Among Lindgren's works, that were favourite to the parents, are also: "Ronya, the Robber's Daughter", "Karlsson Who Lives on the Roof", "Emil i Lönneberga", "The Brothers Lionheart".

2) Fairy-tales

The following tales are most preferred:

Reworked/adapted by: Hans Christian Andersen; Charles Perrault; The Brothers Grimm.

Among the most read are also: Bulgarian folk fairy-tales; Tales of other nations; One Thousand and One Nights fairy-tales.

3) Antoine de Saint-Exupéry ("The Little Prince")

4) Lewis Carroll ("Alice in Wonderland")

5) Gianni Rodari ("The Adventures of Luccio", "Telephone tales")

6) Authors of adventure literature-Karl May ("Winnetou"); Jack London (The White Fang, The Call of the "Wild"); Daniel Defoe ("Robinson Crusoe"); Jules Verne ("Captain Nemo"); Mayne Reid ("Osceola the Seminole"); Liselotte Welskopf-Henrich ("The Sons of Great Bear") etc.

7) Erich Kästner (“Das doppelte Lottchen", "Pünktchen und Anton”, "When I Was a Little Boy")

8) Mark Twain ("Tom Sawyer", "The Prince and the Pauper")

9) Alan Alexander Milne ("Winnie-the-Pooh")

10) Alexandre Dumas-father ("The Three Musketeers")

11) Eno Raud ("Маншон Naksitrallid")

12) Carlo Collodi ("Pinocchio")

13) Hugh Lofting ("Doctor Dolittle")

14) Hector Malot ("Without Family") 
15) Jonathan Swift (“Gulliver's Travels")

16) Lyman Frank Baum (“The Wonderful Wizard of Oz”)

17) Johanna Louise Spyri ("Heidi”)

The most read Bulgarian authors and titles among the surveyed parents were:

1) Ran Bosilek ("Patilantsi")

2) Angel Karaliychev (“Toshko African”, “Bulgarian folk tales”, “Aneto”)

3) Elin Pelin ("Jan Bibian", "Stories")

4) Boris Aprilov ("The Adventures of Lisko")

From the data presented in Figure 15, we can conclude that the classic children's works continue to be preferred by more than half of parents' readings for their children. Nearly $19 \%$ of respondents have not yet offered their favourite children's book to their child, but plan to do so in the future. About $1 / 4$ of the studied general population tends to focus mainly on new works of children's literature, now available on the book market. Among the books in traditional format for 8 - 12 year olds in recent years with high sales on the book market have established titles such as "The Diary of a Drundyo" by Jeff Keaney (a series of 5 books published by "Duo Design"), the series "Little Nicholas" (Kolibri Publishing) by Rene Gossini and Sempe-10 books plus two adapted for the little ones, Knister's Lily the Wonder (26 books, A \& T Publishing), Rachel Rene Russell's "The Diaries of a Loser" - a series of 4 books published by "Artline Studios" (Mineva, Svetlana 2014). To them I could add, for example, "Grandma the Bandit"-(a series of 10 books published by "Duo Design" by David Williams). Among the titles in the series are: "Demon Dentist", "Ratburger", "Mr. Stinker", "The Boy with the Dress", etc., which speak for themselves, as well as many of the editions listed above, for dubious artistic value and educational effect.

From the data presented in Table 16 it becomes clear, that for more than half of the children reading "happens" sometimes, rarely or not at all. In this regard, I would like to recall what Radostina Neykova [29] from the Institute for the Study of Arts of the Bulgarian Academy of Sciences shared: "It is a well-known

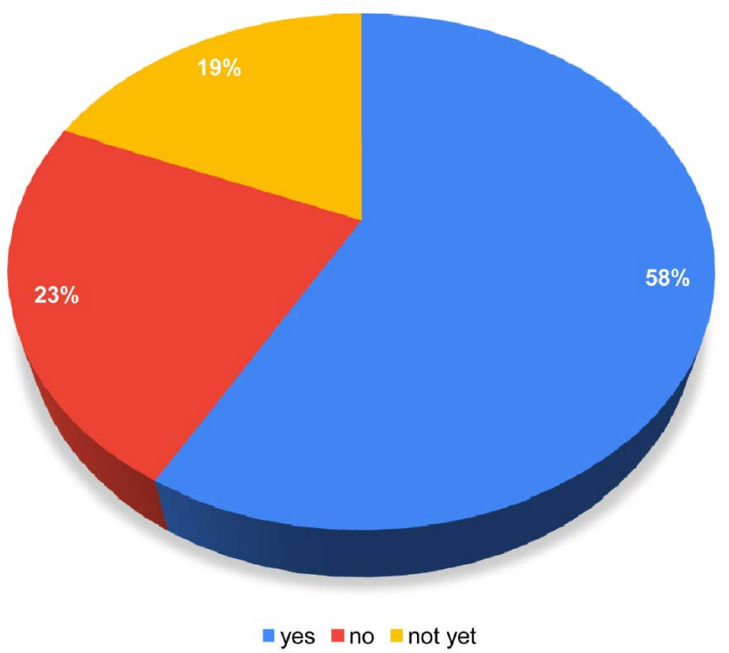

Figure 15. The parent's favourite children's book read by the child. 
Table 16. Reading among the child's circle of friends.

\begin{tabular}{ccc}
\hline Do your child's friends read books? & number & percentage \\
\hline no & 120 & 10.3 \\
rarely & 276 & 23.6 \\
sometimes & 277 & 23.7 \\
yes, they do & 476 & 40.7 \\
yes, they read a lot of books & 20 & 1.7 \\
\hline
\end{tabular}

fact that long before the literary era (not to mention the computer age), namely based on the fairy tales (and myths, orally transmitted, I would add) the children were introduced to the different forms of communication, to the different basic aesthetic categories such as good and evil, beautiful and ugly, etc. Today, the era of literature has been replaced by the era of vision. Over pre-built screen images the children get acquainted with the basic aesthetic concepts, moral values, and most of all attractively presented visual emotions, feelings and experiences. It is increasingly difficult for them to tell an event or experience with the help of words alone. Even the use of comics in the field of education is also beginning to be applied due to the need for an image of easier and more accessible perception in telling a story. That is why classic literary works such as 'Treasure Island' by Robert Louis Stevenson, 'The Hunchback of Notre Dame' by Victor Hugo and others are now published on the book market in comics format, even in Bulgaria. And perhaps this remains a leading trend in contemporary art for childrenthe predominance of vision over literary form, of modern narrative, reaching even the absence of narrative, over classical story".

In answering the question "How many books are there in your home library?", it is noticeable the fact that rich family libraries gradually melt away over the years in different generations. Only $14.4 \%$ of the responding parents indicate that they have a rich library (over 500 volumes), $10.3 \%$ report that they have a library with various readings in the amount of 300 to 500 volumes, and for $29.7 \%$ of the respondents this volume is in the range from 100 to 300 volumes. Most often (42\%) the number of books in home libraries is between 10 and 100, and $3.6 \%$ say they do not collect books. Taking into account that the completion of the questionnaire is voluntary and anonymous, it can be assumed that respondents respect reading and are aware of its importance for the intellectual development of the child and his/her transformation into a person with a well formed worldview and value system. In response to a previous question, the parents indicate that most often their children use books from the home library (51.8\%) or they buy them from a bookstore (23.3\%). In this regard, the fact that the variety of children's readings at home is not great is worrying. It is a wellknown fact that at an early age children are brought up as readers primarily at home. Reading parents most often have reading children.

The established statistically significant difference between the volume of home libraries in large cities and smaller settlements is also noticeable. The results are presented in Table 17. 
Table 17. Volume of libraries in children's homes.

\begin{tabular}{cccccc}
\hline Settlement & $\mathrm{N}$ & $\mathrm{SD}$ & $\mathrm{M}$ & $\mathrm{F}$ & Sig. \\
\hline over 1 million inhabitants & 315 & 0.40 & 3.24 & & \\
up to 500000 inhabitants & 210 & 0.42 & 2.94 & & \\
up to 100000 inhabitants & 124 & 0.51 & 2.87 & & \\
up to 50000 inhabitants & 172 & 0.45 & 2.71 & & \\
up to 10000 inhabitants & 156 & 0.05 & 2.56 & & \\
up to 5000 inhabitants & 60 & 0.09 & 2.83 & & \\
up to 1000 inhabitants & 34 & 0.12 & 2.82 & & \\
up to 500 inhabitants & 48 & 0.09 & 2.83 & & \\
\hline
\end{tabular}

Table 18. Relationship between the volume of the home library and the place where the child most often uses books.

\begin{tabular}{cccc}
\hline Number & \multicolumn{1}{c}{ Questions } & No. 8 & No. 15 \\
\hline $\mathbf{8}$ & Where does your child most often use books from? & $\star$ & $0.372^{\star *}$ \\
15 & How many books are there in your home library? & & $\star$
\end{tabular}

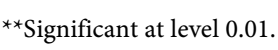

Why is it important for children to have their own library? In this regard, I especially like the view of Albert Benbasat. He is referring to the traditional paper book. "Reading is a kind of game-for both children and adults. Library collection-too. However, something very important: children live according to the principle of pleasure (Sigmund Freud) and do not distinguish play from serious everyday problems and activities." [30]. What is beyond the pleasure principle?pleasure again, but a more mature and guaranteed that pleasure will happen in time. Which itself corresponds to satisfaction. The involvement of important brain centres and functions in reading leads to their development and ultimately-to the development of personality intellect.

The correlation analysis between the factors of the volume of the home library and the place from where the child most often tends to use books shows a moderate non-parametric correlation (Spearman, $r=-372$ ). The correlation is significant at level 0.01 (Table 18).

\section{Conclusions}

In conclusion, we can note that the results of the study show that the traditional practices of children's reading (in a traditional format, especially at home or in the home of grandparents, using the home library) are preserved in modern society. These traditional practices of children's reading remain popular in primary school age, despite the active processes of globalization and informatization.

The new reading practices of modern children in primary school are characterized mainly by new, different from those of their parents' generation genrethematic preferences (comics, horror, as well as a more pronounced interest in 
military-themed readings), as well as the more frequently read scientific cognitive, encyclopaedic literature.

The change in reading motives can also be attributed to the new reading practices. The trend of reading on the Internet with the increasing of the age of children is also among the new practices that are slowly but surely making their way.

The new genre-thematic preferences, the change in the main motives for reading and the entry of the reading into the electronic environment are closely related to the entry of the new information and communication technologies.

Over $90 \%$ of elementary school students use the Internet and other electronic devices, but most of them do not read books there. The still preferred format for reading books is the traditional one, although there is a tendency with age to shift this preference in favor of the electronic format. The number of students using library books or consultations with librarians is relatively low. The book is a desirable gift by children. It is necessary to pay a lot of patience and perseverance by parents, by the school and by the library community to take care of the formation of their reading habits and tastes.

\section{Acknowledgements}

We express our deep gratitude to all school principals and teachers who distributed the survey questionnaire. Thanks to the parents or guardians of the children who filled it out. Without your responsiveness, commitment and help, this study would not have been possible.

This study is carried out under within a Project under contract No. CP 06M35/3 of 18.12.2019 on the subject: "Study of modern educational programs of cultural institutions in Bulgaria" led by Dr. Sonya Spasova, funded by the Fund "Scientific Research" at the Ministry of Education and Science.

\section{Conflicts of Interest}

The authors declare no conflicts of interest regarding the publication of this paper.

\section{References}

[1] Nikolova-Ivanova, D. (2016) The Perception of a Text When Reading in Bulgarian Language Teaching. Methodological Aspects (5th-7th Grade). PhD Thesis, University of Veliko Tarnovo.

[2] Mincheva, R. (2018) Formation of Reading Competencies through Interactive Learning in Bulgarian Language (as a First Language) - 2 Grade. PhD Thesis, Sofia University, Sofia.

[3] Demirdjian, P. (2018) Psychological Specifics of the Relationship: Reading a Work of Art-Experiencing Empathy-Altruistic Action. PhD Thesis, Varna Free University, Varna.

[4] Stamboliyska, M. (2016) Sensitivity and Learning of Primary School Students. PhD Thesis, Sofia University, Sofia.

[5] Todorova-Markova, G. (2016) The Relations Difficulties in Reading-Reproduction 
and Comprehension of a Read Text in Students with Mental Retardation 1 - 4 Grade. PhD Thesis, Sofia University, Sofia.

[6] Ignatova, D. (2014) Diagnostic Model for Assessment of Preschool Children at Risk for Specific Reading Disorders. PhD Thesis, Sofia University, Sofia.

[7] Tsenova-Ivanova, C. (2011) Norms for Correct Writing and Screening of Signs of Dyslexia in Students of 2nd, 3rd and 4th Grade. PhD Thesis, Sofia University, Sofia.

[8] Stamenova, I. (2018) Development of Reading Literacy of Students in 4th Grade in Terms of Project-Based Learning. PhD Thesis, Southwestern University.

[9] Borisova, M. (2016) The Public Library-A Partner in the Education of Children and Students. PhD Thesis, University of Library Science and Information Technology.

[10] Mircheva, I. (1988) Education of Reading Interests of the Students from I-III Grade. PhD Thesis, Sofia University, Sofia.

[11] Georgieva, A. (2004) Reader Profile of Students from First to Fourth Grade. PhD Thesis, Sofia University, Sofia.

[12] Atanasov, G. (1973) Discussions on Aesthetic Education [of Students]. Narodna Prosveta, Sofia.

[13] Parizhkova, L. (2019) Alpha Generation and Reading. Education and Technology. Innovations in Teaching and Cognitive Development, 10, 7-12.

[14] Eftimova, S. (2019) About the Libraries and Children. Contemporary Strategies and Innovations in the Knowledge Management: Collection with Papers of the Fifth Scientific Conference, 26-30 August 2019, Geneva. Academic Publishing House "Za bukvite-O Pismenech", Sofia, 5: 25-34.

[15] Clark, C. (2019) Children and Young People's Reading in 2017/18. Findings from Our Annual Literacy Survey.

https://cdn.literacytrust.org.uk/media/documents/Reading trends in 2017-18.pdf

[16] Kolosova, E. (2011) Children's Reading Practices: The Results of a Comprehensive Study, Moscow. https://ekimovka-x.ru/files/sociolog/kolosova kniga .pdf

[17] Sushko, N. and Petrova, L. (2009) Analysis of the Reading Interests of Children and Adolescents: Problems of Reading, Publishing and Availability of Printed Materials. In Belarusian State Technological University. Proceedings of BSTU. Minsk, 9, 97-101.

[18] McGeown, S., Osborne, C., Warhurst, A., Norgate, R. and Duncan, L.G. (2016) Understanding Children's Reading Activities: Reading Motivation, Skill and Child Characteristics as Predictors. Journal of Research in Reading, 39, 109-125. https://doi.org/10.1111/1467-9817.12060

[19] McGeown, S., Bonsall, J., Andries, V., Howarth, D. and Wilkinson, K. (2020) Understanding Reading Motivation across Different Text Types: Qualitative Insights from Children. Journal of Research in Reading, 43, 597-608. https://onlinelibrary.wiley.com/doi/10.1111/1467-9817.12320 https://doi.org/10.1111/1467-9817.12320

[20] Therrell, J. (2002) Age Determination Guidelines: Relating Children's Ages to Toy Characteristics and Play Behaviour.

https://www.cpsc.gov/s3fs-public/pdfs/blk pdf adg.pdf

[21] Davcheva, E. (2014) On the Children's Reading and Parents-With Love for the Future or with Reprehensible Carelessness? Biblioteka, 3-4, 174 -183.

[22] Scholes, L. (2019) Differences in Attitudes towards Reading and Other School-Related Activities among Boys and Girls. Journal of Research in Reading, 42, 485-503.

https://doi.org/10.1111/1467-9817.12279 
[23] Conradi, K., Jang, B.G. and McKenna, M.C. (2014) Motivation Terminology in Reading Research: A Conceptual Review. Educational Psychology Review, 26, 127-164. https://doi.org/10.1007/s10648-013-9245-Z

[24] Baker, L. and Wigfield, A. (1999) Dimensions of Children's Motivation for Reading and Their Elations to Reading Activity and Reading Achievement. Reading Research Quarterly, 34, 452-477.

https://msu.edu/ dwong/CEP991/CEP991Resources/Baker\&Wigfield-MotivRdng.pdf https://doi.org/10.1598/RRQ.34.4.4

[25] Guthrie, J.T. and Wigfield, A. (2000) Engagement and Motivation in Reading. In: Kamil, M.L., Mosenthal, P.B., Pearson, P.D. and Barr, R., Eds., Handbook of Reading Research, Erlbaum, Mahwah, 3: 403-422.

[26] Schiefele, U., Schaffner, E., Möller, J. and Wigfield, A. (2012) Dimensions of Reading Motivation and Their Relation to Reading Behaviour and Competence. Reading Research Quarterly, 47, 427-463.

[27] Wigfield, A. and Guthrie, J.T. (1997) Relations of Children's Motivation for Reading to the Amount and Breadth of Their Reading. Journal of Educational Psychology, 89, 420-432. https://doi.org/10.1037/0022-0663.89.3.420

[28] Wang, J.H.-Y. and Guthrie, J.T. (2004) Modelling the Effects of Intrinsic Motivation, Extrinsic Motivation, Amount of Reading, and Past Reading Achievement on Text Comprehension between U.S. and Chinese Students. Reading Research Quarterly, 39, 162-186. https://doi.org/10.1598/RRQ.39.2.2

[29] Neykova, R. (2014) Contemporary art and Children's Literature-Between the Traditional and the Digital. In: Children and Reading-Between the Traditional and the e-Book: A Collection of Reports from a Round Table, Sliven, 7-9 May 2014, Regional Library “Sava Dobroplodni”, Sliven, 231.

[30] Benbasat, A. (2014) How Important Is the Personal Library for the Child. In: Children and Reading-Between the Traditional and the e-Book. A Collection of Reports from a Round Table, Sliven, 7-9 May 2014, Regional library "Sava Dobroplodni”, Sliven, 35. 